\title{
The Utilization of Residue Come Out as a By-Product by the Cold Press
}

\section{Naime NT*, Zeliha S, Ali G, Sıdıka B0, Hale Feyza B, Yasemin G and} Beril K

Middle East Technical University, Turkey

\section{Research Article}

Volume 3 Issue 1

Received Date: January 11, 2019

Published Date: January 28, 2019

DOI: $10.23880 /$ oajpr-16000172

*Corresponding author: Naime Nur Temiz, Middle East Technical University, Zade Vital Pharmaceutical Chemicals Food Industry and Trade Inc., Büyükkayacık OSB Mah. Güzel Konak Sok. 8B-1 Selçuklu/KONYA, Tel: +90 53435474 87;

Email: ntemiz@zade.com.tr

\section{Abstract}

In recent years, with the increase of the world population, the studies on the utilization of the herbal wastes resulting from increased industrialization and production have gained speed and importance. Vegetable oils take a large part in the formation of herbal wastes, especially in industrial areas. Vegetable oil wastes (residue) obtained by the cold press method which has been used since ancient times are thought to be richer in nutritional values as they are produced without using heat. In this study, protein, sugar, mineral, and calorie assays of the residues of Nigella Sativa, Wheat germ, Coconut, Grape seed, Fig seed, and Walnut which were generated as a by-product after cold press fixed oil extraction were investigated.

Keywords: Cold Press, Residue, Bagasse, Herbal Residue, Waste, Waste Utilization, Recycling, Recovery

\section{Introduction}

Many different extraction methods are available in the production of vegetable oils. Among these, the main method known and used since ancient times is the cold press method. A simple mechanical pressure is applied in the oil production by the cold press. The use of solvents, as in the refining process, is not available, nor is there any kind of heat by external intervention [1]. Therefore, the cold press method does not require much energy. Although the amount of oil extracted by the refined method is higher than the amount of oil extracted by the cold press, the nutritional value of the residue obtained by the cold press is richer as they undergo less degradation [2]. The color, sensory, and nutritional values of the oils extracted by this method have been shown to be of good quality [3].
In recent years, with the increase of the world population, the studies on the utilization of the herbal wastes resulting from increased industrialization and production have gained speed and importance. In particular, there are many studies on the recovery and utilization of organic raw material waste. Recovery of herbal wastes will contribute to the utilization of sustainable environmental waste as well as to the national economy.

In this study, the use of residue in the food industry, which contains important components in terms of nutrients and is produced as a by-product in consequence of the process following the fixed oil extraction by the cold press method, were investigated. In the study, the residues of Nigella Sativa, Wheat germ, Coconut, Grape seed, Fig seed, and Walnut obtained by the cold press 


\section{Open Access Journal of Pharmaceutical Research}

method were used. These residues are foodstuffs with very rich nutritional value. Residues create large amounts of food wastes and are used to produce products with low economic value (animal feed, fertilizer, etc.) [4] Moreover, with the recovery of wastes, it is aimed to provide added value economically, to increase product variety, and to be used as a raw material providing economic recovery. As the consumption of food increases due to the recent increase in population, the need for raw materials also enhances [5]. Therefore, it is expected that the residues obtained will be used in the production of new food products with rich content and will provide a return to the national economy.

\section{Material and Methods}

In the study, the residues of Nigella Sativa, Wheat germ, Coconut, Grape seed, Fig seed, and Walnut obtained by the cold press method were used. Protein, Sugar, Mineral content assays in these residues along with calorie calculation of the residues were made. Protein quantification was performed by the Kjeldahl method, sugar quantification by the Lane-Eynon method, mineral quantification using ICP/OES, and calorie quantification using Calorimetry (Figure 1).

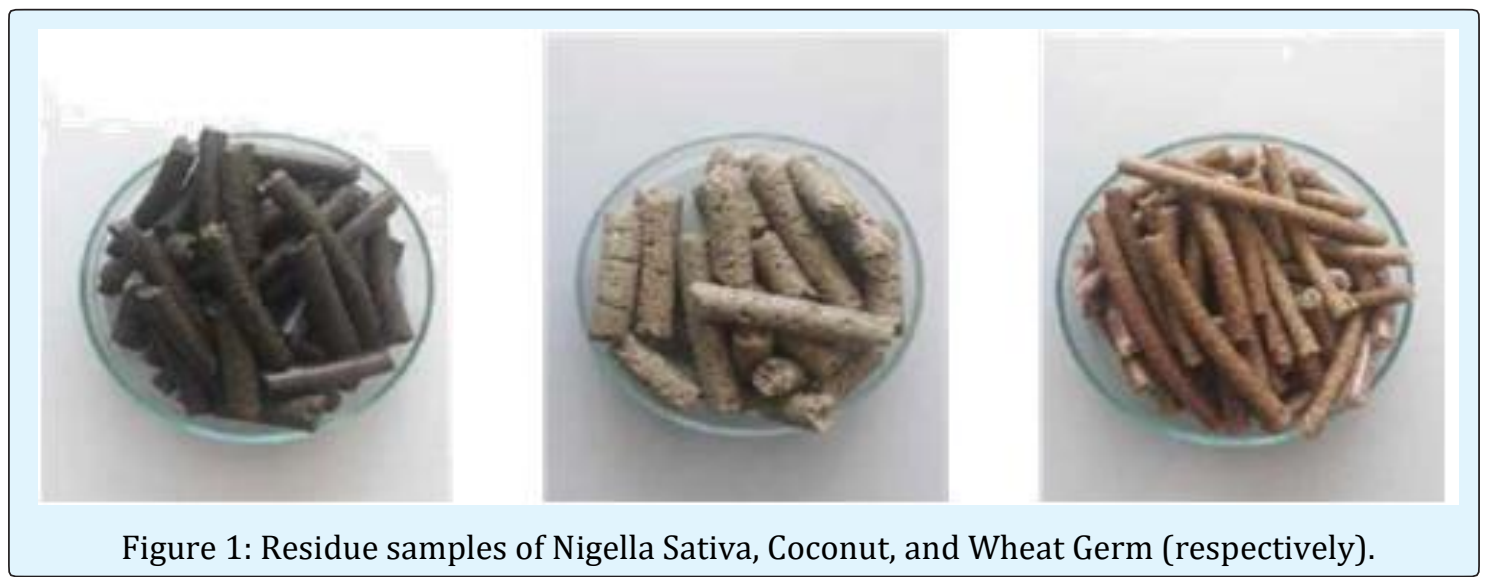

\section{Protein Quantification}

The protein quantification in the residues of Nigella Sativa, Wheat germ, Coconut, Grape seed, Fig seed, and Walnut obtained by the cold press method was done using the Kjeldahl method. $1 \mathrm{~g}$ of the sample was transferred to Kjeldahl tube after weighing. $25 \mathrm{ml}$ of Sulfuric acid was added with the catalyst. After placed in Kjeldahl incineration unit, $10 \mathrm{ml}$ of Hydrogen Peroxide was added. It was incinerated at $420 \mathrm{C}$ for $30 \mathrm{~min}$.

A few drops of indicator were instilled to the $25 \mathrm{ml}$ of boric acid solution in the flask and it was placed in distillation unit together with the cooled Kjeldahl tube. 50 $\mathrm{ml}$ of pure water and $100 \mathrm{ml}$ of sodium hydroxide solution were added slowly. Distillation procedure was started and was continued until the flask containing $25 \mathrm{ml}$ of boric acid becomes a total of $150 \mathrm{ml}$. Finally, titration was carried out with $0.1 \mathrm{~N}$ hydrochloric acid solutions.

\section{Sugar Quantification}

The sugar quantification in the residues of specified vegetable oils extracted after the cold press method was done using the Lane-Eynon method. The $\mathrm{Cu}$-II ion, which is in the alkaline environment and at the boiling temperature, was reduced by the reducing sugars to the $\mathrm{Cu}-\mathrm{I}$ oxide when starting the analysis. An alkali complex $\mathrm{Cu}$ solution was titrated to the solution prepared from the sugar-containing sample. Methylene blue was used as an indicator. After all copper was reduced to $\mathrm{Cu}-\mathrm{I}$ oxide, titration was terminated when the methylene bluecontaining solution turned to a colorless form. The solution turned to a color of red copper. Calculations were made based on the consumption amount.

\section{Mineral Quantification}

Mineral quantification in obtained residues was done using Shimadzu/ICPE 9000 (ICP-AES Multitype ICP Emission Spectrometer) device. First, $0.5 \mathrm{~g}$ of sample was weighed and placed in the incinerator. $7 \mathrm{ml}$ of Nitric acid and $1 \mathrm{ml}$ of Hydrogen peroxide were added in the container. It was placed in the incineration unit and method was selected from the control panel of the device. The incinerators were opened after cooling and the sample taken into ICPE 9000 tubes was placed in the autosample. Reading was done on the device by the method for mineral quantification (European Pharmacopoeia 8.0) [6] and results were obtained (Figure 2). 


\section{Open Access Journal of Pharmaceutical Research}

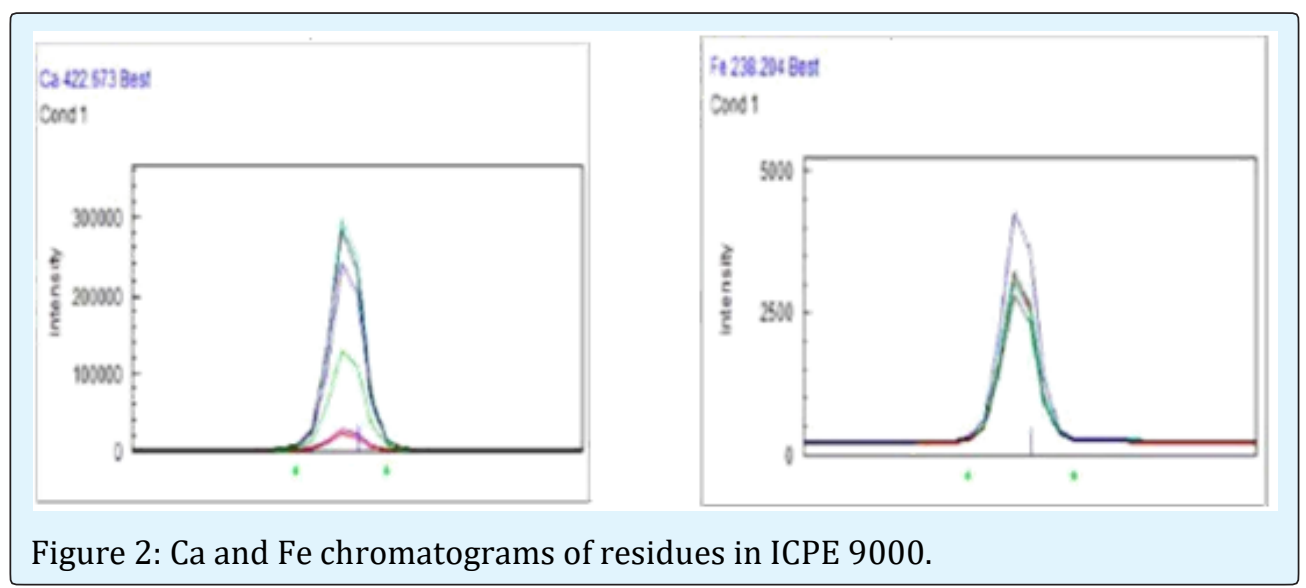

\section{Calorie Quantification in Residues}

Calorie quantification in residues was done using IKA Calorimeter C 200. $0.5 \mathrm{~g}$ of sample was weighed and placed in the tube of the device. 02 was given in the tube to start incineration and the tube was placed in the device. After incineration was completed, the result was calculated.

\section{Results}

According to the analysis results, the Protein and Sugar quantities in the residues used in the study and Calorie calculations of the residues were given in Table 1 and the Mineral quantities in Table 2.

\begin{tabular}{|c|c|c|c|}
\hline $\mathbf{1 0 0 g}$ & Protein & Sugar & Calorie \\
\hline Residue of Gape Seed & $13 \mathrm{~g}$ & $2.4 \mathrm{~g}$ & $485 \mathrm{cal} / \mathrm{g}$ \\
\hline Residue of Fig Seed & $18 \mathrm{~g}$ & $1.5 \mathrm{~g}$ & $465 \mathrm{cal} / \mathrm{g}$ \\
\hline Residue of Coconut & $21 \mathrm{~g}$ & $10 \mathrm{~g}$ & $485 \mathrm{cal} / \mathrm{g}$ \\
\hline Residue of Wheat Germ & $29 \mathrm{~g}$ & $12 \mathrm{~g}$ & $460 \mathrm{cal} / \mathrm{g}$ \\
\hline Residue of Walnut & $42 \mathrm{~g}$ & $6.1 \mathrm{~g}$ & $475 \mathrm{cal} / \mathrm{g}$ \\
\hline Residue of Nigella Sativa & $33.5 \mathrm{~g}$ & $3.8 \mathrm{~g}$ & $485 \mathrm{cal} / \mathrm{g}$ \\
\hline
\end{tabular}

Table 1: Protein, Sugar and Calorie values of the Residue of Grape Seed, the Residue of Fig Seed, the Residue of Coconut, the Residue of Wheat Germ, the Residue of Walnut \& the Residue of Nigella Sativa in $100 \mathrm{~g}$.

\begin{tabular}{|c|c|c|c|c|c|}
\hline $\mathbf{1 0 0 g}$ & K & P & Fe & Zn & Ca \\
\hline Residue of Gape Seed & $115 \mathrm{mg}$ & $215 \mathrm{mg}$ & $8 \mathrm{mg}$ & 0 & $510 \mathrm{mg}$ \\
\hline Residue of Fig Seed & $78 \mathrm{mg}$ & $319 \mathrm{mg}$ & $13 \mathrm{mg}$ & $2.68 \mathrm{mg}$ & $522 \mathrm{mg}$ \\
\hline Residue of Coconut & $247 \mathrm{mg}$ & $301 \mathrm{mg}$ & $9.5 \mathrm{mg}$ & 0 & $41 \mathrm{mg}$ \\
\hline Residue of Wheat Germ & $180 \mathrm{mg}$ & $602 \mathrm{mg}$ & $8.3 \mathrm{mg}$ & $6 \mathrm{mg}$ & $50 \mathrm{mg}$ \\
\hline Residue of Walnut & $213 \mathrm{mg}$ & $573 \mathrm{mg}$ & $8 \mathrm{mg}$ & $2.14 \mathrm{mg}$ & $221 \mathrm{mg}$ \\
\hline Residue of Nigella Sativa & $212 \mathrm{mg}$ & $550 \mathrm{mg}$ & $8 \mathrm{mg}$ & $2.35 \mathrm{mg}$ & $526 \mathrm{mg}$ \\
\hline
\end{tabular}

Table 2: K (potassium), P (phosphor), Fe (iron), Zn (zinc) \& Ca (calcium) values of the Residue of Grape Seed, the Residue of Fig Seed, the Residue of Coconut, the Residue of Wheat Germ, the Residue of Walnut \& the Residue of Nigella Sativa in $100 \mathrm{~g}$. 


\section{Open Access Journal of Pharmaceutical Research}

\section{Discussion}

In a study [7], residues of different cold press oils were examined in terms of their physicochemical and bioactive properties and the residues were found to be rich in proteins as well as in phenolic compounds, flavonoids, and tannins. In the same study, it was observed that grape seed residue contains significant amounts of fiber and walnut residue has a high content of phenolic, flavonoid, and tannins. According to the results of the study by Karaman S, et al. [7], the amounts of protein in the walnut and grape seed residues were $34.09 \%$ and 9.38\%, respectively. As seen in our results presented in Table 1 , the amounts of protein of $42 \%$ and $13 \%$ were higher than other studies. In this study published in 2015, when the residues (walnut and grape) were compared for minerals, especially potassium, calcium, and phosphorus contents were found to be richer than the values given in Table 2. This difference may result from either the analysis methods used or types of raw materials used and the soil where it grows.

In the light of the results, it was observed that the residues were rich in protein, sugar, and mineral contents.

\section{Conclusion}

The utilization of residues which are quite rich in protein \& sugar, \& mineral contents will provide added value economically and will provide an additional benefit in terms of healthy nutrition because of the enrichment of nutritional and functional properties of foods. The studies to be carried out on this subject will contribute to the development of the food sector in this area by using functional foods enriched in nutritional value, special nutritional foods, sports foods, and other new food products. This situation is expected to contribute to the national economy in the recovery of sustainable environmental wastes.
Acknowledgment: We would like to thank Zade Vital Natural Products Research and Application Center and Zade \& Zade Vital İbn-i Sina R \& D Center for research support during this study.

\section{References}

1. Lutterodt $H$, Luther M, Slavin M, Yin JJ, Parry J, et al. (2010) Fatty acid profile, thymoquinone content, oxidative stability, and antioxidant properties of cold pressed black cumin seed oils. LWT Food Sci Technol 43(9): 1409-1413.

2. Deferne JL, Pate DW (1996) Hemp seed oil: A source of valuable essential fatty acids. Journal of the International Hemp Association 3(1): 1-48.

3. Güler G, Taşan M (2009) Soğuk Presyon Ve Kimyasal Rafinasyon Yöntemleri İle Üretilen Kanola (Kolza) Yağlarının Bazı Fiziksel Ve Kimyasal Özelliklerinin Karşılaştırılması. TC Namık Kemal Üniversitesi Fen Bilimleri Enstitüsü pp: 1-107.

4. Yağcı S, Altan A, Göğüş F, Maskan M (2006) Gıda Atıklarının Alternatif Kullanım Alanları. Türkiye 9. Gida Kongresi pp: 499-502.

5. Yaman K (2012) Bitkisel Atıkların Değerlendirilmesi ve Ekonomik Önemi. Orman Fakültesi Dergisi, 12(2): 339-348.

6. Avrupa Farmakopesi 8.0. NBScience.

7. Karaman S, Karasu S, Tornuk F, Toker OS, Geçgel Ü, et al. (2015) Recovery Potential of Cold Press Byproducts Obtained from the Edible Oil Industry: Physicochemical, Bioactive, and Antimicrobial Properties. Journal of Agricultural and Food Chemistry 63(8): 2305-2313. 